\title{
Reviews
}

\author{
edited by \\ Joshua Parker
}

\section{The Future of US Education}

Joshua Parker, University of Salzburg

Books reviewed:

Kill It to Save It: An Autopsy of Capitalism's Triumph Over Democracy.

By Corey Dolgon (Bristol: Policy Press, 2018), 320pp. The Age of American Unreason in a Culture of Lies.

By Susan Jacoby (London: Vintage Books, 2018), 364pp.

DOI: 10.47060/jaaas.Vii1.67

Donald Trump's election brought a wave of popular books for a general readership trying to make sense, as Hilary Clinton's own analysis of the situation attempted, of What Happened (2017) onto the market. As American studies grapples with an era offering new fodder for thought on what America means as it moves well into the twenty-first century, two new general audience books look for the root causes of the shift in the political tone to study in America itself: namely, primary and secondary US education.

Stonehill College Professor of Sociology Corey Dolgon's Kill It to Save It: An Autopsy of Capitalism's Triumph Over Democracy broadly traces the history and roots of US public education as being from its beginnings in the service of the US economy, but only by the 1990 s openly concerned with becoming profit-making itself. Synthesizing a range of sources from de Tocqueville to Georg Simmel, to Lehman Brothers financial reports, to Noam Chomsky, Dolgon lowers charges against economic austerity, broken health care systems, the food industry, standardized testing and charter schools, "junk science," and what Naomi Klein in 2007 dubbed "the shock doctrine," suggesting a right-wing tactic common to them all: a logic of "kill it to save it," a dangerously "common sense" approach to privatization and corporate profit-seeking within the public sphere. In effect, Dolgon writes, over the past two decades, Americans have "handed over the reins of educational reform to marke- 


\section{3}

Reviews

teers and Madmen" (62).

Postwar mass higher education, writes Dolgon, was militaristic, racist and patriarchal, and made the mistake of "ghettoizing" new fields of cultural studies like women's studies and African American studies as they began to appear as forces in the 1960s. With growing stagnation in federal funding for research over the next decades came "partnerships" with private corporate industry, so that, by 2000, academia had "embraced the language and mimicked the practices of corporations themselves" (94). This resulted in a loss of "national culture," as Bill Readings's The University in Ruins (1996) suggested. "Replacing a commitment to national culture and state-driven imperialism," writes Dolgon, "universities have adopted the language of 'excellence"' (95), a term, Dolgon cleverly notes, "has no meaning outside of comparison"-mainly involving "pseudoscientific proof" of "better" quality through "a language of accounting and assessment, ranking and competition." This, he suggests, is a guise for "outsourcing practically everything: from food, health, and custodial services to staff recruitment, retention management, and-ironicallystrategic planning itself," with the aim of attracting "higher paying students and lower paid faculty and staff" (96). The resulting precarity of academic labor leads, in Chomsky's terms, to a "market McCarthyism" within the university.

The result, Dolgon writes, is a "dumbing down" of curricula to keep students happy, while students themselves in turn perform more and more work of "the selecting and dispersing of services and monitoring and evaluating of employees and logistics" (98). Not only are students provided less challenging material, 60\% graduate with an average student debt of $\$ 33,000$ each. With $40 \%$ of those now delinquent or in default on loans, Andrew Ross has suggested the system might be seen as a form of modern indentured servitude. Increasingly privatized and profit-driven primary public education systems, in which "failing" schools are cut in funding ("killed" in order "to save them"), funneling students into "charter schools" with, on average, worse outcomes, along with state and federal cuts to health care, research, housing, and transportation, Dolgon jokes in his introduction, are enough to make readers want to slit their wrists or hide in a closet. His work draws on a wide range of sources worth looking at, provided in extensive endnotes.

Both Dolgon's book and Susan Jacoby's The Age of American Unreason in a Culture of Lies were begun well before the Trump era, and see the rise of Trump and his appointees as simply an extreme culmination of processes long in development (Jacoby's is an updated version of a 2008 edition). Both are well-crafted, anecdotal portraits of American culture today, covering roughly the same period, the 1960 s to the present, suggesting, as Dolgon puts it, that "America's political and cultural consciousness has been rewired since Reagan" (vi). 


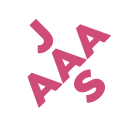

Reviews

Jacoby, too, sees an idealized early postwar period as the "good old days," here not for higher education specifically, but for what she lauds throughout her book as "middle-brow culture." Sprouting from a middle-class, nineteenth-century progressivism, the middle-brow culture of postwar America depended on basic skills in critical thinking, which now seems to be failing contemporary America. Jacoby flags three warning signs of a democracy in danger through mis- or under-education: a populace unable to distinguish between coincidence and causation (a basic requirement for scientific literacy), "the appropriation of scientific-sounding language without underlying scientific evidence or logic," and the average American's "lack of understanding of basic mathematical and statistical concepts" (220). Willfully manipulated and exacerbated by a coalition of political and corporate interests, the three weaknesses are played upon, and Jacoby sees the privatization of American public education as a major tool in the project. Her book's copious citations show how publicly-funded state education like that of neighboring Canada out-performs the programs of US charter schools, online university courses, and private for-profit colleges in the United States. "The crisis in contemporary American education," she writes, "has been treated by politicians, on the left and the right, as an affliction confined to a disadvantaged minority of the young, who can be helped by a concerted effort to raise standardized test scores," all the while gearing education toward standardized testing which does little to teach any of "what citizens of a functioning democracy need to know" (309-10). Both in and out of school programs, she suggests, American students are "in thrall to commercially generated images," and suffering from "historical amnesia."

The picture painted by both authors is dark, and without easy solutions. "The triumph of capitalismover democracy," Dolgonwrites, "is notjustatheoretical platitude from progressive politicos or lefty professors. The real degradation of political discourse and debate, the media's infantilizing of its audiences, and the purposeful dismantling of our rights to be an informed, active electorate (one that actually gets to vote) no longer threaten our democracy-our democracy has been defeated"(208). Both authors largely withhold any tactical suggestions for improvement of the situations they describe (though Dolgon offers a brief overview of recent movements like Black Lives Matter and Occupy Wall Street), viewing the problems they trace and outline not as glitches in the American Dream, but as the intended results of profit-driven private and corporate machinations. Their work isn't a direct call to arms, but a portrait of the otherwise almost invisible landscape in which contemporary Americans find themselves caught. 